Vol. 10 (1): 31-34 (2020)

\title{
DANGEROUS GOODS SUCCESS TEST DEVELOPMENT STUDY
}

\author{
Serpil ÖZKURT SIVRÍKAYA \\ Kocaeli University, Kocaeli Vocational School, Chemistry Department, Kocaeli, Turkey; \\ Corresponding Author Serpil ÖZKURT SIVRIKKAYA, e-mail: s_sivrikaya@yahoo.com;
}

Received November 2019; Accepted December 2019; Published January 2020;

DOI: https://doi.org/10.31407/ijees10.104

\begin{abstract}
This is a valid and reliable achievement test for dangerous materials. The universe of this study consists of the students of Kocaeli Vocational School of Chemical Technology. The research was applied to 190 students studying chemistry program in Kocaeli Vocational School in 2018-2019 academic year. The achievement test, which measures dangerous substances, is a measurement tool applicable to vocational school degree students.
\end{abstract}

Key words: Dangerous materials ecology, achievement test, quantitative research 